\title{
THE POLITICS IN THE CANADIAN JUDICIAL DECISION MAKING PROCESS: ECONOMIC ANALYSIS OF TAX LITIGATION
}

\author{
BERRY F.C. HSU
}

The application of economic theories, rightly or wrongly, has a major impact on our lives. Economic reform inevitably leads 10 political reform. However, it remains unanswered whether economic reform leads to reform in the judicial decision making process. Although there are a number of studies on the economic analysis of taxation, that is, the study of economics and tax policies, there is virtually no literature on the economic analysis of tax cases.' The time is ripe for a study of the connection between economic analysis and case law in taxation as Canada approaches the twenty-first century. This article investigates whether the federal courts in Canada have taken economic reality into consideration in making their decisions on tax matters. This is the first attempt to address the issue; although somewhat exploratory and speculative, it provides a starting point.

This article first discusses tax scholarship in Canada. Then, the relevance of law and economics is discussed with special emphasis on the use of economic tools to analyse common law cases. From these discussions, the theories of economics are linked to tax cases. Finally, the author analyses the trend of applying economic analysis in federal tax cases. This article should serve as a starting point for a future analysis of the cases determined by the Supreme Court of Canada.
$\dot{A}$ tort ou à raison, l'application des théories économiques a une incidence notable sur nos vies. Les réformes économiques entraînent inévitablement des réformes politiques. Il n'est cependant pas évident qu'elles aient une incidence sur le processus décisionnel judiciaire. Bien qu'un certain nombre d'études portent sur la fiscalité, l'économie et la politique fiscale, les travaux d'analyse économique consacrés à la jurisprudence fiscale sont pour ainsi dire inexistants. Alors que le Canada se prépare à

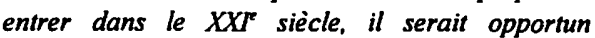
d'étudier les liens existant entre l'analyse économique et la jurisprudence fiscale. L'auteur examine si les tribunaux canadiens tiennent compte de la réalité économique quand ils tranchent en matière de fiscalité. Bien que la démarche adoptée soit exploratoire et hypothétique, notons que le sujet est abordé pour la première fois et qu'il constitue un point de départ.

$L$ 'auteur se penche d'abord sur les travaux consacrés à la fiscalité au Canada. Il examine ensuite la pertinence du droit et de l'économie, et met l'accent sur le recours aux outils économiques dans l'analyse du droit jurisprudentiel courant. Puis, l'auteur établit le lien entre les théories économiques et les poursuites fiscales. Il étudie finalement la tendance qui consiste à appliquer l'analyse économique en droit fiscal fédéral. Le présent article devrait servir de point de départ $\dot{a}$ l'analyse des décisions prises par la Cour suprême du Canada en la matière.

\section{TABLE OF CONTENTS}

I. INTRODUCTION ... . . . . . . . . . . . . . . . 742
A. TAX LAW AS AN
AUTONOMOUS DISCIPLINE $\ldots \ldots \ldots \ldots \ldots \ldots \ldots 74$

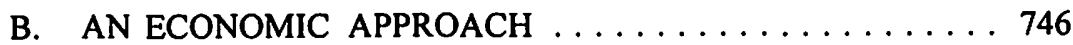
II. METHODOLOGY N MEASURING
ECONOMIC REALITY

- $\quad$ B.Sc., LL.M. (Alberta); M.A. (Oregon); Ph.D. (London); C.Eng. (U.K.); Assistant Professor of Law and Taxation, Hong Kong University of Science and Technology. I wish to thank my colleagues, Dr. Joseph Cheung and Dr. Joseph Lin, for their valuable comments. Any errors are my own.

I One exception to this is Y. Grbich, "Is Economics Any Use to Tax Lawyers? Towards A More Substantial Jurisprudence To Replace Legalism" (1980) 12 Melb. U.L. Rev. 340-355. 


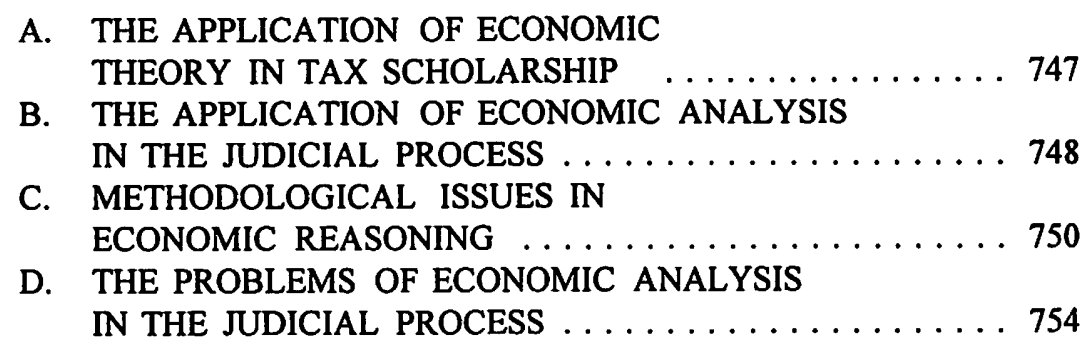

III. ECONOMIC REALITY IN FEDERAL COURT CASES . . . . . 756

A. EMPLOYER AND EMPLOYEE

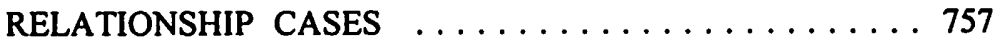

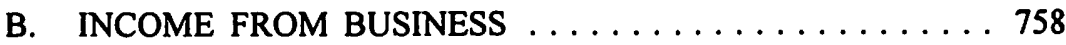

C. ADVENTURE OR CONCERN IN

THE NATURE OF TRADE $\ldots \ldots \ldots \ldots \ldots \ldots \ldots \ldots \ldots$

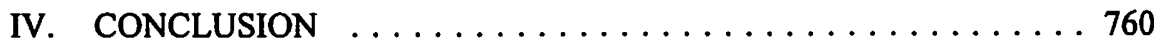

\section{INTRODUCTION}

The Arthurs Report ${ }^{2}$ raised several issues in legal scholarship. It called for changes in traditional Canadian legal education in order to encourage more fundamental research. In the area of tax law, we have to examine how it is made and administered, its impact on our economy and on our political and social life, and its cultural significance. The judicial decision making process in tax law is an area which is under-researched. ${ }^{3}$

Canadian tax scholarship tends to assume that the legal reasonings provided by the judiciary determine the outcome of cases, and that judicial decision making is neutral and largely autonomous. ${ }^{4}$ Legal scholars in Canada seldom use any of their research on legal interpretation to inquire into the systematic methodology of the courts. ${ }^{5}$ An

Consultative Group on Research and Education in Law, Law and Learning: Report to the Social Sciences and Humanities Research Council of Canada (Ottawa: Minister of Supply and Services, 1983) [hereinafter the Arthurs Report].

Almost twenty years after the publication of the Arthurs Report, journals dedicated to fundamental research have finally made an inroad into the Canadian academic world (for example, the Canadian Journal of Law and Society, the Canadian Journal of Legal Studies, the Canadian Journal of Family Law, and the Canadian Journal of Women and the Law). These journals are edited by faculty boards rather than by the traditional student-controlled law review boards. The growing amount of interest in fundamental research in Canada has raised a question as to the boundaries between the legal scholar's study of the tax law and the work of sociologists, economists, or political scientists writing about tax law. See N. Brooks, "Future Directions in Canadian Tax Law Scholarship" (1985) 23:3 Osgoode Hall L.J. 441 at 444. Canadian legal scholarship, however, has been dedicated mostly to the area of doctrinal scholarship. A survey of Canadian law journals has revealed that tax law research in Canada focuses mostly on treating taxation as a set of rules and delineating what it is. See Brooks, ibid. at 445-446. This type of scholarship, however, is an important contribution by legal scholars to the professional community. It has been observed that tax law scholarship in Canada takes on formalism seriously. Ibid. at 453.

Brooks, ibid. at 453-454.

Ibid. at 454. 
integration of doctrinal and fundamental research can be used to examine the extent to which economic reality ${ }^{6}$ affects the judicial decision making process.

In common law jurisprudence, the introduction of economic analysis in law was not advocated by academics until the early 1960s.' The judicial movement in the common law world to adopt an economic approach was not developed until the 1970s. ${ }^{8}$ Therefore, it is modern day jurisprudence that we must investigate.

\section{A. TAX LAW AS AN AUTONOMOUS DISCIPLINE}

As taxation is a statutory field, its rules of law as discussed in conventional textbooks and law reviews are well settled and not as uncertain as other areas of law. However, the application of the Canadian Charter of Rights and Freedoms ${ }^{9}$ to taxation is still developing.

A remarkable number of articles in tax law are in the area of tax planning. ${ }^{10}$ Once a taxpayer finds a loophole to avoid tax, the government can easily make good the defect before presenting its next fiscal bill. Revenue Canada has provided Advance Rulings services. These rulings are considered binding only with respect to the taxpayer to whom they are issued."

In expounding tax statutes, a strict interpretation approach has been adopted in the common law tradition, subject to modification. ${ }^{12}$ The consequence has been to strengthen the certainty of tax law. This evolution can be traced back to English jurisprudence. The strict interpretation rule in tax law was adopted by the British House of Lords in Partington v. Attorney General, ${ }^{13}$ and was applied when the taxpayer was avoiding the tax that would otherwise be payable in C.I.R. v. The Duke of Westminster. ${ }^{14}$ However, in Furniss (Inspector of Taxes) v. Dawson, Lord Scarman said:

The term "economic" will be discussed later in this article. "Reality" here refers to a real thing, fact, or state of things. Economic reality encompasses inter alia economic analysis and economic approach. In an economic analysis, economic methodologies and theories are being applied. The economic methodologies and theories can be used by the courts in the judicial decision making process or can be used to analyse the case decided by the court. In an economic approach, the results reported by economists are accepted by the courts without the necessity of applying any economic methodology or theory.

R. Posner, "The Law and Economic Movement" (1987) 77:2 Am. Econ. Rev. 1-13.

It was only during President Ronald Reagan's term (1981-1988) that proponents of law and economics began to be appointed to the bench because of their views. The notable ones are Judges Robert Bork, Richard Posner, Frank Easterbrook, and Antonin Scalia.

Part I of the Constitution Act, 1982, being Schedule B to the Canada Act 1982 (U.K.), 1982, c.11 [hereinafter Charter].

Brooks, supra note 3 at 446.

Information Circular No.70-6R; D.M. Sherman, Income Tax Research (Don Mills: De Boo, 1989) 68 and 99-100.

12 V. Krishna, "Developments in the Law of Income Taxation: The 1985-86 Term" (1987) 9 Supreme Court L. Rev. 487-494. 
Whatever a statute may provide, it has to be interpreted and applied by the courts; and ultimately it will prove to be in this area of judge-made law that our elusive journey's end will be found. ${ }^{15}$

This decision does not really support a strict interpretation approach, and the Supreme Court of Canada took the view that the ratio decidendi of I.R.C. v. The Duke of Westminster was "too deeply entrenched in our tax law for the courts to reject it in the absence of clear statutory authority." ${ }^{16}$ The strict interpretation approach has been modified by Canadian tax courts to suit economic reality. In Stubart Investments Ltd. v. Her Majesty the Queen, Justice Estey wrote:

Income taxation is also employed by government to attain selected economic policy objectives. Thus the statute is a mix of fiscal and economic policy. The economic policy element of the Act sometimes takes the form of an inducement to the taxpayer to undertake or redirect a specific activity. ${ }^{17}$

Traditionally, law is an autonomous discipline in that it is a subject entrusted only to lawyers. ${ }^{18}$ Tax law is becoming less autonomous. In addition to being a statutory law, it is an area that every taxpayer has to deal with. Economists have to study its feasibility and implications, and accountants have to operate within its rules. In tax law, common law doctrines apply only in interpretation. The Charter has not had a demonstrable impact on the wide power of Revenue Canada under the Income Tax Act. ${ }^{19}$

Although the courts have followed s. 12 of the Interpretation $A c t^{20}$ and have provided a logical interpretation of the Charter, they appear to be reluctant to override a tax provision by virtue of the Charter.$^{21} \mathrm{~A}$ survey of all the constitutional challenges to the Income Tax Act up to 1990 has shown that out of seventeen cases, including one search and seizure case, ${ }^{22}$ the taxpayers have lost all but one in the courts. ${ }^{23} \mathrm{~A}$ case in point is Symes v. Her Majesty the Queen, ${ }^{24}$ an equality case, in which the Federal Court of Appeal subsequently allowed the appeal of the Crown. ${ }^{25}$ If the above figures

[1984] 1 All E.R. 530 (H.L.).

In Stubart Investments Ltd. v. Her Majesty the Queen, [1984] C.T.C. 294, 84 D.T.C. 6305 (S.C.C.), the Supreme Court of Canada rejected the argument that the lack of a business purpose is a sufficient reason to ignore a legally effective tax planning. However, the possibility that some sort of business purpose test may still be relevant in interpreting a particular provision of the Income Tax Act is still left open. See T.E. McDonnell \& R.B. Thomas, "The Supreme Court and Business Purpose: Is There Life After Stubar?" (1984) 32 Can. Tax J. 853 at 854.

[1984] C.T.C. 294, 84 D.T.C. 6305 (S.C.C.) at $6321-6322$.

R. Posner, "The Decline of Law as an Autonomous Discipline: 1962-1987" (1987) 100 Harv. L. Rev. 761.

S.C. 1988, c. 55 .

R.S. 1985, c. I-23, s. 11. This section provides that: "[e]very enactment is deemed remedial, and shall be given such fair, large and liberal construction and interpretation as best ensures the attainment of its objects."

D.W. Ross, "Constitutional Tax Cases" (1990) 3:1 Can. Curr. Tax J1-J8.

McKinlay Transport Lid. et al. v. The Queen, [1990] 90 D.T.C. 6243 (S.C.C.); R.B. Thomas, "Demand for Information Not a Violation of the Charter" (1990) 38 Can. Tax J. 372.

Ross, supra note 21 at J6-J7.

[1989] 89 D.T.C. 5243 (F.C.T.D.).

[1991] 91 D.T.C. 5397 (F.C.A.). 
are any indication, taxpayers are well advised to think carefully before considering similar litigation. Such an approach by the judiciary is not unexpected if economic reality is taken into account.

The results of a Charter violation simply mean that the government of the day may have to refund monies to a large number of taxpayers who are affected by the decision. In Air Canada v. British Columbia ${ }^{26}$ the Supreme Court of Canada held that the successful appellant, Air Canada, could not recover the money paid by its passengers for the tax on alcoholic beverages as it was acting as an agent collecting it under the Act. It is economically unrealistic to return taxes previously paid. In some other areas, like criminal law, at most a few hardened criminals can get away on technicalities. In the area of tax law, a substantial section of the population might suffer as a result of the government's need for revenue to achieve its economic objectives.

Because of its statutory nature, the development of tax law is limited. Some authorities argue for the demise of the strict interpretation rule to allow room for expansion of the law. ${ }^{27}$ However, tax law is a self-contained area. For example, it does not follow the traditional master and servant test developed in contract and tort laws in determining whether a taxpayer has entered into a contract of service or a contract for service. ${ }^{28}$

In some other areas, where common law has to fill in the gap, the tax court has its own judicial development. For example, it looks at what actually happens rather than at the prescribed legal formalities in determining the "location" of the management and control of a corporation ${ }^{29}$ and in distinguishing whether a profit is an ordinary income or a capital gain. ${ }^{30}$ The equitable rule of estoppel is of no avail against the Crown as the taxpayers cannot reasonably claim to rely on the form as some sort of promise by the Crown. ${ }^{31}$ This is one of the reasons why expert system developers consider tax law an easier field in which to advance their Artificial Intelligence theories since reasoning begins from explicit rules enacted by Parliament. ${ }^{32}$

Canadian Pacific Airlines Lid. v. British Columbia; Air Canada v. British Columbia, [1989] 1 S.C.R. 1133.

Krishna, supra note 12; V. Krishna, "The Demise of the Strict Interpretation Rule" (1986) 1:28 Can. Curr. Tax J135.

Boardman v. Her Majesty the Queen, [1979] C.T.C. 159, 79 D.T.C. 5110 (F.C.T.D.); Wiebe Door Services Lid. v. M.N.R., [1986] 2 C.T.C. 200, 87 D.T.C. 5025 (F.C.A.).

Unit Construction Co. Lid. v. Bullock, [1959] 3 All E.R. 831, [1960] A.C. 351 (H.L.); Sifneos v. M.N.R., [1968] 68 D.T.C. 522.

Regal Heights Limited v. M.N.R., [1960] C.T.C. 384, 60 D.T.C. 1270.

It has been accepted by Canadian courts that the doctrine of estoppel may operate against the Crown. See Grobowsky v. M.N.R., [1986] T.C.J. No.1, Action No. 85-262 (UI).

A. von der Lieth Gardner, An Artificial Intelligence Approach to Legal Reasoning (Cambridge: M.I.T. Press, 1987) at 5. 


\section{B. AN ECONOMIC APPROACH}

One important question for analysis is whether there is a tendency towards using the economic approach in judicial decision making. ${ }^{33}$ A review of cases indicates the presence of both patent and latent approval of such an approach. For example, in Stubart Investments Ltd. v. Her Majesty the Queen, the Court made it clear that:

[w]ithout the inducement offered by the statute, the activity may not be undertaken by the taxpayer for whom the induced action would otherwise have no bona fide business purpose.... At minimum, a business purpose requirement might inhibit the taxpayer from undertaking the specified activity which Parliament has invited in order to attain economic and perhaps policy goals. ${ }^{34}$

\section{In Her Majesty the Queen v. Phyllis Barbara Bronfman Trust, the Supreme Court} said:

Assessment of taxpayers' transactions with an eye to commercial and economic realities, rather than juristic classification of form, may help to avoid the inequity of tax liability being dependent upon the taxpayer's sophistication at manipulating a sequence of events to achieve a patina of compliance with the apparent prerequisites for a tax deduction. ${ }^{35}$

Tax law is a set of rules used to enforce the economic and fiscal policy of the government of the day. The political ideology of the government in power would probably lead it to make changes in tax provisions in order to advance its political objectives. In theory, the judiciary is independent. In practice, judges come from different backgrounds, depending on the political party in power which appoints them. In any country, judicial decisions are inevitably affected by judicial ideology. There is

The conflict between responsibility to legal professionals and intellectual creativity in the academic world has been experienced by most scholars of tax law. Legal scholars have strong affiliations with members of the legal profession and their research is often cited in memoranda of law and taken seriously by the judiciary. On the other hand, legal scholars have an obligation to their own academic community to take a critical approach to the system and to pursue the truth, for example, whether there are any institutional limitations on judicial decision making in tax cases.

It is suggested in the Arthurs Report, supra note 2 that "[t]here is an apparent tension between the human-intellectual goals of a law faculty and its professional-training activities." In fairness, it also stated that "law schools also encourage students to develop intellectual insights and, to some extent, to identify standards of reason, of justice, of effectiveness."

Although tax law is generally regarded as a practical subject, there is no reason why it cannot develop into a "new, more introspective personality." The academic study of its social and economic implications would humanize what was conceived as a purely professional topic for lawyers and accountants. At present, most of the research in these areas is conducted by economists.

In researching the economic aspect of Canadian tax law, the Carter Report has marked a new era. It is the most comprehensive Canadian report addressing the relationship between economic, social, and political issues and revenue collection. Some of its recommendations have been accepted by the government of the day and some have been gradually phased in. See I.H. Asper, The Carter Report (Montreal: Equitable Income Tax Foundation, 1969). 
ample research, both theoretical and empirical, to support this assumption. ${ }^{36}$ However, studies have also shown that judges are not necessarily consistently liberal or

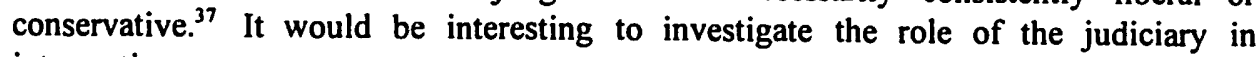
interpreting tax statutes.

Judges are individuals who have their own predilections, prejudices and rational processes. ${ }^{38}$ Research has shown that in important constitutional issues, the justices of the Supreme Court of Canada have hidden their political calculations under the guise of legal reasoning. ${ }^{39}$ This leads to the suggestion that judges may also disguise their personal values in the judicial decision making process. ${ }^{40}$ An analysis of tax cases could provide some clues as to whether the judiciary has taken economic reality into account.

\section{METHODOLOGY IN MEASURING ECONOMIC REALITY}

There are two distinct types of economic analysis of law. The first, known as normative analysis, attempts to explain what the law should be for the betterment of society. ${ }^{41}$ The second, known as positive analysis, attempts to explain what the law is, has been, or will be, and to explain what the world is. ${ }^{42}$ Economic analysis has been based on the assumption that people are rational maximizers of their satisfactions. ${ }^{43}$ Therefore, law can be best understood and explained in terms of promoting the efficient allocation of resources. ${ }^{44}$ The concept of efficiency is the maximizing the net value of resources. ${ }^{45}$ We shall try to take the second approach to investigate whether Canadian tax cases support the assumption that judicial interpretations tend to promote economic efficiency.

\section{A. THE APPLICATION OF ECONOMIC THEORY IN TAX SCHOLARSHIP}

The advancement of legal scholarship in the field of taxation is closely related to the development of economists' techniques. The complex general-equilibrium economic

A.D. Head, "The Charter in the Supreme Court of Canada: The Importance of Which Judges Hear an Appeal" (1991) 24:2 Can. J. Pol. Sc. 289-307; S.R. Peck, "An Analytical Framework for the Application of the Canadian Charter of Rights and Freedoms" (1987) 25 Osgoode Hall L.J. 1; D. Lloyd, The Idea of Law (London: Penguin Books, 1973) at 212-220; G. Schubert, "Political Culture and Judicial Ideology" (1977) 9 Comp. Pol. Stud. 363-408; J.A.G. Griffith, The Politics of the Judiciary (London: Fontana Paperbacks, 1981) at 187-216; R. Cotterrell, The Sociology of Law (London: Butterworths, 1984) at 228-258.

P. McCormick \& I. Greene, Judges and Judging (Toronto: James Lorimer \& Co., 1990) at 72.

Head, supra note 36 at 290.

M. Gold, "The Mask of Objectivity: Politics and Rhetoric in the Supreme Court of Canada" (1985)

7 Supreme Court L. Rev. 455-510.

lbid.

For some pioneering works, see G. Calabresi, The Cost of Accidents: A Legal and Economic Analysis (New Haven: Yale University Press, 1970); R. Posner, "Some Uses and Abuses of Economics in Law" (1979) 46 U.C.L.R. 281.

Posner, ibid. at 287.

Ibid. at 282.

R. Posner, Economic Analysis of Law, 2d ed. (Toronto: Little Brown and Co., 1977) at 16-17.

Ibid. at 10-12. 
models can be used to estimate the effect of wealth distribution. Such models would cover every possible behaviourial response to alternative tax rules. ${ }^{46}$ This type of analysis has been used to a certain extent by scholars in Canada. The extent to which the Canadian courts accept this economic analysis and evidence will be investigated.

In the application of economic analysis to law, Ronald Coase is one of the pioneers with his article, "The Problem of Social Cost". ${ }^{47}$ His idea is known as the Coase Theorem which earned him a Nobel Prize in 1991. Coase is a firm believer in governmental non-intervention, advocating that with private disputes it is best to allow parties to sort out their differences in economic terms. According to Coase, if there is no transaction cost (for example legal cost), then an efficient outcome will result regardless of the legal rules, that is, no matter who is being assigned the legal right. If there is a transaction cost, then the efficient outcome may not occur under every legal rule. The preferred legal rules would be those which would minimize the transaction cost.

\section{B. THE APPLICATION OF ECONOMIC ANALYSIS IN THE JUDICIAL PROCESS}

From time to time, common law judges do justify their opinions beyond the doctrine of stare decisis by resorting to moral, political, institutional and other social considerations. ${ }^{48}$ Judges often must resort to these exterior sources in cases where no relevant precedents are available, when making a first impression decision, where two relevant precedents do not reconcile, where the change in circumstances necessitates the reconsideration of old authorities, and where the scope of a precedent has to be defined. After all, legal theories are merely a set of dogmas which judges and lawyers apply to justify the outcome of a case according to their wishes. ${ }^{49}$

In $R$ v. Askov ${ }^{50}$ the Supreme Court of Canada expressly took economic reasons into account in determining the existence of systematic or institutional delay. Legal scholars have argued that these exterior sources prevail over appeals to authority in the common law. ${ }^{51}$ The introduction of economic analysis to the judicial decision making process has been advocated by an increasing number of academics over the past twenty-

It has been predicted that legal scholarship in taxation will enter a new era as these economic models are further developed. See Brooks, supra note 3 at 464 .

R.H. Coase, "The Problem of Social Cost" (1960) 3 J. Law \& Econ. 1.

R.S. Summers, "Two Types of Substantive Reasons: The Core of a Theory of Common Law Justification" (1978) 63 Cornell L. Rev. 707. At common law, there is a doctrine of public policy that operates to take account of social interests. See R. Pound, "A Survey of Social Interests" (1943) 57 Harv. L. Rev. 1; M.P. Furmston, ed., Cheshire, Fifoot, and Fumston's Law of Contract, 11 th ed., (London: Butterworths, 1986) at 376-409. A judicial decision might well be legally sound, but it could also be condemned as harsh by the public if it does not conform with economic reality.

M. Tushnet, "Following the Rules Laid Down: A Critique of Interpretivism and Neutral Principles" (1983) 96 Harv. L. Rev. 781 at 821-822.

(1990), 74 D.L.R. (4th) 355 (S.C.C.).

Summers, supra note 48 at $730-734$. 
five years. ${ }^{52}$ According to two American jurists, few judges have taken an economic analysis approach in reaching their decisions other than in those cases which deal with monopoly regulation and the like. ${ }^{53}$

However, some have observed that economic logic has been guiding the judicial decision making process. ${ }^{54}$ It has been observed that there is a recent trend towards using economic analysis in the United States federal courts. ${ }^{55}$ A review of Canadian scholarly literature sheds very little light on the existence of these exterior reasons in the judicial decision making process. The decision of the British House of Lords in British Railways Board v. Herrington ${ }^{56}$ shows that the availability of resources to the defendant is an important factor in determining tortious liability, although in this case the economic cost to the community was not considered. The court would require a higher standard of care from a large corporation. The British law lords made their decision in line with modern social conditions and humanitarian principles.

In measuring the extent to which economic reality affects the judicial decision making process, pure doctrinal work in legal scholarship is insufficient. Recent research has asserted that the knowledge of a judge plays an important role in any decision making process, and that creative ideas are exposed to social pressures. ${ }^{57}$ In the sphere of the judicial decision making process, it has been argued that the education and experience of a judge produce a "mind-set" with regard to the outcome of a case. ${ }^{58}$ Therefore, methodologies from other disciplines are borrowed.

Judicial decision making and public policy making are inevitably interwoven. ${ }^{59}$ In adjudicating cases, judges have to operate within the legal framework. They have to follow the statutes and common law rules in interpreting tax cases in order to achieve public policy goals. On the other hand, legislators are subject only to constitutional restraint and the political and economic structure in formulating their public objectives. However, both judges and legislators in reaching a decision on public policy matters are influenced by their values. ${ }^{60}$

For example see R. Posner, "Utilitarianism, Economics, and Legal Theory" (1978) 8 J. Legal Stud 103; J.M. Miller, "Economic Analysis of Legal Method and Law: The Danger in Valueless Values" (1985-86) 21 Gonz. L. Rev. 425; G. Cohen, "Posnerian Jurisprudence and Economic Analysis of Law: The View from the Bench" (1985) $133 \mathrm{U}$. of Pa. L. Rev. 1117. R.S. Summers \& L.B. Kelley, "'Economists' Reasons' for Common Law Decisions - A Preliminary Inquiry" (1981) 1 Oxford J. 213 at 214.

s4 Posner, supra note 44 at 25-29. L.H. Tribe, "Court Weighs Principles and Finds Them Wanting" The Los Angeles Times (22 July 1984).

[1972] A.C. 877; (1972) 88 L.Q.R. 310 (H.L.).

R. Hogarth, Judgement and Choice (Toronto: John Wiley \& Sons, 1987) at 132-150; Posner, supra note 41 at $153-175$.

D. Armstrong, "My Lady of the Law is No Economist; My Lady Competition Law is No Lady" in F. Mathewson et al., eds., The Law and Economics of Competition Policy (Vancouver: Fraser Institute, 1988) at 392-398. For a discussion, see ibid. at 7-8. 
We all know that tax law is a statutory field and judicial interpretation is inevitable. Common law plays a major role in judicial interpretation. In interpreting statutes, the judiciary often goes beyond querying the meaning of the relevant provisions and assumes a role of judicial creativity. ${ }^{61}$ According to an analysis by one leading jurist, the judiciary fills in the gaps which the legislature fails to foresee. ${ }^{62}$ In applying economic analysis to adjudicating tax cases there is ample space for the judiciary to be creative within the legal framework.

Some legal scholars tend to believe that anything beyond reading statutes, comparing cases and exercising critical reasoning is outside their ambit. ${ }^{63}$ Such a view seems narrow-minded. In the analysis of a particular problem in tax law, such a tendency does not enable tax scholarship to investigate the needs of society. Tax scholarship should be able to consider problems relating to economic and social circumstances, ${ }^{64}$ bring in ideas from other disciplines and deal with problems as economists and psychologists would.

\section{METHODOLOGICAL ISSUES IN ECONOMIC REASONING}

Robert S. Summers and Leigh B. Kelly have developed a model for economic analysis in common law decisions. ${ }^{65}$ The exterior reasons as discussed above are called "substantive reasons". According to Summers \& Kelly, "goal reasons" and "rightness reasons" are the two basic types of substantive reasons to be found in common law cases. Goal reasons support a decision which serves a good social goal. ${ }^{66}$ Rightness reasons support a decision which accords with a socio-moral norm of rightness as applied to a party's past actions or to a state of affairs resulting from those actions. ${ }^{67}$ In terms of economic analysis, goal reasons can be sub-classified into Pareto-superior reasons and Kaldor-superior reasons as they serve social objectives. ${ }^{68}$

\section{Pareto-superior Reasons}

One of the objectives of Canadian tax policy is the reallocation of resources and redistribution of wealth in order to achieve social goals. In measuring whether a particular tax policy has achieved horizontal and vertical equity in an efficient manner, economists have devised measurement techniques. One of these is attributed to Vilfredo Pareto (1848-1923). ${ }^{69}$ According to Pareto, a reallocation of resources is Pareto-superior to an antecedent allocation if it makes "no person worse off and at least

H. Jones, "Statutory Doubts and Legislative Intention" (1940) 40 Colum. L. Rev. 957 at 970; R. Dickerson, The Interpretation and Application of Statutes (Toronto: Little, Brown and Co., 1975) at 23 .

Jones, ibid. at $971-972$.

Brooks, supra note 3 at 444.

Ibid. at 474.

Supra note 53.

Ibid. at 213.

Ibid. at 214.

Ibid. at 215.

Ibid. 
one person better off."70 This is in answer to Bentham's utilitarianism: measuring happiness across the people in determining the effect of the policy on total utility." Courts do decide cases in terms of maintaining family harmony, enhancing public convenience and promoting better labour-management relations.

The reallocation of resources can be performed in many ways. It can be done by private parties bargaining in a free market: there will be give and take in the allocation of resources. Reallocation can also be achieved by a single individual who makes a decision for both parties, for example, in an adjudication process. In the sphere of tax law, settlements are sometimes made by taxpayers, who have limited bargaining power with Revenue Canada, rather than resorting to common law. In reaching a Pareto-superior decision, a common law judge would apply the economic analysis.

A Pareto-superior reason is relevant only to justify a change or to justify not making a change. ${ }^{72}$ In making a change, at least one person would be better off and no one would be worse off. In not making a change, no one would gain or someone would lose. When Pareto-superior reasoning is taken into account, the common law judge must act intra vires, that is, they must have the power to allocate resources.

There are four types of common law situations relevant to the application of Pareto-superior reasoning. In a situation where the judge is merely applying common law precedents and not deciding whether to depart from the status quo, a Pareto-superior reason is irrelevant. ${ }^{73}$

A second type of case is where the common law court is faced with the choice of whether to make new law, by overruling or modifying an existing right of a party. ${ }^{74}$ Under such circumstances, Pareto-superior reasoning is used by the court to decide whether someone would be better off and no one would be worse off, or otherwise. In the sphere of the employment relationship, the Federal Court of Appeal has reversed a Tax Court's decision and indicated a reluctance to follow the single criterion test. In Wiebe Door Services Ltd. v. M.N.R., ${ }^{75}$ the Court looked at the whole scheme of operations to determine the master and servant relationship. Obviously, the successful applicant was better off. Although the Minister of Revenue could not collect the Unemployment Insurance Premiums and Canada Pension Plan contributions, it simply

A situation is said to be Pareto-efficient if there is no change from that situation which can make no person worse off and at least one person better off. Conversely, a situation is not Pareto-efficient if there can be change from that situation which makes no person worse off and at least one person better off. See P.A. Samuelson \& W.D. Nordhaus, Economics, 13th ed. (New York: McGraw-Hill Book Company, 1989) at 747-749; J.L. Coleman, "Efficiency, Exchange, and Auction: Philosophic Aspects of the Economic Approach to Law" (1980) 68 Cal. L. Rev. 221; R. Posner, "The Ethical and Political Basis of the Efficiency Norm in Common Law Adjudication" (1980) 8 Hofstra L. Rev. 487 at 488.

Posner, ibid. Note that utilitarianism is criticized for allowing individual injustice by its preoccupation with the greatest good for the greatest number of people.

Supra note 53 at 222.

Ibid.

Ibid.

Supra note 28. 
had no legal obligation to provide these services to those affected, and those affected had an understanding that they would be regarded as independent contractors who would in turn be responsible to Revenue Canada. Therefore, no one, including the loser, would be worse off.

A third type of situation is in cases of first impression. ${ }^{76}$ The court is bound to create new law, although it is often a matter of degree as to how much the case of first impression overlaps existing cases. From the outset, the rights of both parties are uncertain. The common law court must assign a right to each party so that both parties would be better off than at the starting point, that is, at least one party would be better off and no one would be worse off. In this case, Pareto-superior reasoning can support a decision. A taxpayer who loses his case under section 245 of the Income Tax Act and is denied tax benefits arising from an avoidance transaction would not be worse off unless a penalty is imposed: he would have to pay tax had there been no such avoidance arrangement. However, Revenue Canada would be better off: it did not know whether the court would consider the particular arrangement to be bona fide, and, hence, has no existing right.

The last type of situation is in cases where the precedents cannot be reconciled. ${ }^{77}$ From the outset, the rights of both parties are uncertain. The situation would be the same as above. Alternatively, there can be a loser if one of the parties is assumed to hold the right in question to any degree.

The court can always inquire about the kind of settlement the parties would agree to should the actual dispute arise. From the inquiry, the court can then apply Pareto-superior analysis to the last three types of situations. This would be speculative. In most common law cases, the above Pareto-superior situations rarely arise. ${ }^{78}$

\section{Kaldor-superior Reasons}

In a Kaldor-superior situation, there is a loser as well as a gainer, but the gainer's gains are such that he could compensate the loser's losses and still have some gain left. ${ }^{79}$ No actual compensation need be paid. Insofar as the gainer gains more than the loser loses, a Kaldor-superior reallocation is considered as efficient in achieving the goal of overall welfare improvement. However, economists find it difficult to compare gains and losses of different persons as this would be subjective.

In Day \& Ross Ltd. v. Her Majesty the Queen, ${ }^{80}$ the taxpayer was allowed deductibility of fines as business expenses under paragraph 18(1)(a) of the Income Tax Act. Although the taxpayer was the loser by paying the fines, the Court considered these as reasonable expenses made for the purpose of gaining or producing income, that

Supra note 53 at 223.

lbid.

For a detailed discussion, see Posner, supra note 70 at 502-507.

Ibid. at 490-492; supra note 53 at 224.

[1976] C.T.C. 707, 76 D.T.C. 6433 (F.C.T.D.). 
is, for the efficient running of the business. ${ }^{81}$ Therefore, its losses were compensated by the income it made. The Court did not consider the deduction as an "outrageous transgression of public policy." ${ }^{182}$

In most common law cases, one side would win and the other side would lose. However, a Pareto-superior reallocation contemplates no losers. The Kaldor-superior criterion would then be available while the Pareto-superior criterion would not.

\section{The Limits of Economic Reasoning in Law}

In order to adjudicate a case by applying economic analysis, a judge has to accept some economic basis in deciding what is a cost and what is a benefit and in assigning societal values to various costs and benefits. ${ }^{83}$ The judge must weigh competing values with a common denominator and often has to convert them into pecuniary terms. Short of having a common denominator, the analysis would not be economic analysis according to this definition.

There are two issues relating to economic analysis in law. One is the extent to which the judiciary should apply economic analysis. A line has to be drawn in applying economic reasoning between what is traditionally the jurisdiction of the courts and what is traditionally the jurisdiction of the legislators. Constitutional questions will undoubtedly arise as well as questions about the training and background of the judges in applying economic theories and scientific evidence (for example, statistical data used to verify the economic theory) in the judicial decision making process. Can the courts apply economic analysis better than the legislators? ${ }^{84}$ There are two schools of thought in applying economics to law. ${ }^{85}$ The Chicago school advocates that only those arguments that are acceptable to economists are appropriate forms of legal arguments. ${ }^{86}$ The Yale school believes in the application of economic analysis as a pervasive role in the making of better judicial decisions. ${ }^{87}$ We shall discuss these practical problems in the following sections.

The second issue is what kind of analysis can be called economic analysis. The goals of economic analysis could be the redistribution of wealth and power or the enhancement of efficiency. We have discussed this previously.

Section 67 of the Income Tax Act provides that the expenses must be reasonable in the circumstances. In Moldowan v. Her Majesty the Queen, [1977] C.T.C. 310, 77 D.T.C. 5213 (S.C.C.), Dickson J. established an objective test as to whether or not any business had a reasonable expectation of profits. This objective determination had to be made from all the facts. See also M.N.R. v. Eldridge, [1964] C.T.C. 545, 64 D.T.C. 5338 (Ex.).

$82 \quad$ Supra note 80 at 718 .

R. Bork, "The Role of the Courts in Applying Economics" (1985) 54 Antitrust L.J. 21 at 22. Note W. Parsons, "The Inefficient Common Law" (1983) 92 Yale L.J. 862 at 885-887 [hereinafter "Inefficient Common Law"].

Ibid.

Ibid. at 930. 


\section{THE PROBLEMS OF ECONOMIC ANALYSIS IN THE JUDICIAL PROCESS}

The application of economic analysis in the judicial decision making process has been a topic of academic debate. Some proponents tend to suggest that economic analysis can resolve all the problems in common law jurisprudence; ${ }^{88}$ some take a different view. ${ }^{89}$

Some American jurists argue against such an approach by reason that constitutional issues are circumvented, ${ }^{90}$ that is, an economic approach in judicial decision making presupposes a schedule of prices in which options can be weighed on society's scale rather than a particular aspect of a case. ${ }^{91}$ Although the application of economic analysis in law might provide some rationality, caution has to be taken to avoid frustrating genuine judicial understanding of the merit of each case..$^{92}$ The judiciary has to make hard constitutional choices in reaffirming and creating, selecting and shaping "the values and truths we hold sacred." ${ }^{.93}$ It is the duty of the judges "to hold up before us the sort of society we desire so that we may be helped, not simply to live by our ideals, but to gain in our understanding of what our ideals are and what they may require of us. ${ }^{194}$

In the sphere of taxation legislation, the judiciary has a duty to interpret it and to apply the doctrine of precedent. It has a duty to ascertain the intention of Parliament. The judiciary is not prohibited from taking economic reality into consideration in accordance with social circumstances. ${ }^{95}$ It has been argued that the role of the judiciary is to support the free market economy because maximizing free choice by individuals will maximize social wealth. ${ }^{96}$ Thus the government's efforts to advance equality, to redistribute wealth and power, and to protect particular groups from exploitation should be limited.97 Some proponents of economic analysis of law take the view that resources can be utilized efficiently in a free market economy. ${ }^{98}$ On the practical side, people who come to court are more interested in winning a case than in setting a precedent. For the advocates of using economic analysis in the judicial decision making process, courts are a societal mechanism for resource allocation. If this approach is

F. Easterbrook, "Method, Result, and Authority: A Reply" (1985) 98 Harv. L. Rev. 622. Posner, supra note 44 at $19-23$.

L.H. Tribe, "Constitutional Calculus: Equal Justice or Economic Efficiency?" (1985) 98 Harv. L. Rev. 592; For an article on the exchange between Easterbrook and Tribe, see E. Fox, "The Politics of Law and Economics in Judicial Decision Making: Antitrust as a Window" (1986) 61 Pol. of L. \& Econ. 554-588.

Tribe, ibid. at 606 .

P. Wald, "Judicial Review of Economic Analyses" (1983) I Yale J. on Reg. 43.

Tribe, supra note 90 at 595 .

E. Spaeth, "Where is the High Court Heading?" (1985) Summer Judges at 48.

The "reasonable limit" clause in section 1 of the Charter and the "remedial" and "fair, large and liberal construction and interpretation" clauses of section 12 of the Interpretation Act provide the judiciary with very wide authority to interpret the tax statute.

P. Wald, "Limits on the Use of Economic Analysis in Judicial Decisionmaking" (1987) 50:4 L.C.P. 225 at 226.

Ibid.

Supra note 44 at 9. 
taken, then it is possible that the future effects of the judicial rulings prevail over the immediate interests of the vying parties. ${ }^{99}$ This is a departure from the traditional view that each case should be determined according to its own merit and runs the risk that the court would decide important issues without considering all the circumstances. ${ }^{100}$ In any event, a court decision can have a precedent-setting effect and will affect future events. Moreover, the Constitution ${ }^{101}$ is based on the assumption that the interests of society can be best served by protecting the rights and freedoms of the individual, ${ }^{102}$ and, hence, it may be viewed as anti-majoritarian and anti-democratic.

Most economic analyses focus on efficiency and avoid the issue of fairness in resource allocation. Economists are more concerned with methods of preventing future occurrence and reducing costs. ${ }^{103}$ The parties in the case at bar are concerned with the merit of the case itself and have no interest in the future. ${ }^{104}$ However, advocates of law and economics suggest that the spirit of the common law is simply the pursuit of efficiency. According to Paul Rubin, resorting to the court will be less likely where the legal rules are efficient. ${ }^{105}$ According to Richard Posner, "common law exhibits a deep unity that is economic in character." ${ }^{106}$ In a routine court case, the allocation of the resource is often the subject matter. ${ }^{107}$ There will be a winner and a loser. If the court adopts such an economic view, who will be there to deliver individual justice?

Chief Judge Wald of the United States Court of Appeal questioned the ability of the judiciary to analyse economic techniques and to ascertain assumptions. According to her, the analysis is complicated by "controversial, powerful, and purposefully comprehensive assumptions about human beings, society and courts." 108 Moreover, the backgrounds of the judges prevent the advancement of this new ideology which encompasses economic, social, and political relationships. ${ }^{109}$

In the American school of jurisprudence, a mechanism based on economic analysis of how the legislative process operates has been formulated to interpret statutes. ${ }^{110}$ In the legislative process, the influence of pressure groups is inevitable. Therefore, law might serve the interests of the vocal groups more than the public at large. According to the advocates of this approach, private interest laws are merely "deals" between the legislators and the pressure groups. Such private laws should be interpreted narrowly

F. Easterbrook, "The Supreme Court, 1983 Term - Foreward: The Court and the Economic System" (1984) 98 Harv. L. Rev. 4 at 10-12.

100 D. Shapiro, "Mr. Justice Rehnquist: A Preliminary View" (1976) 90 Harv. L. Rev. 293.

101 Constitution Act 1982, being Schedule B to the Canada Act 1982 (U.K.), 1982, c.11.

${ }_{102}$ A. Kozinski, "Foreword" in J. Dorn \& H. Manne, eds., Economic Liberties and the Judiciary (Fairfax: George Mason University Press, 1987) at xv.

103 Posner, supra note 44 at 18.

104 lbid.

los P. Rubin, "Why is the Common Law Efficient?" (1977) 6 J. Legal Stud. 51.

106 Supra note 44 at 179-191.

107 J. Hirshleifer, "Evolutionary Models in Economics and Law: Cooperation Versus Conflict Strategies" (1982) 4 Res. L. \& Econ. 1 at 5, 46.

Supra note 96 at 227.

lbid. at 228-230.

"Inefficient Common Law", supra note 84 at 885-887; Wald, supra note 96 at 240-241. 
while the laws which serve public interest should be construed broadly to advance their purpose. ${ }^{111}$ This again departs from the traditional view of a judiciary who should not inquire into the operation of the legislative process but should only give effect to the intent and purpose of the legislation. ${ }^{112}$

\section{ECONOMIC REALITY IN FEDERAL COURT CASES}

We shall discuss a few cases where the federal courts in Canada have taken an economic approach in their judicial decision making process. As we are concerned only with economic reality, the cases selected are those where the courts specifically referred to and applied the economic reality test. We have discussed the various theories relevant to the economic analysis of law in the preceding chapter. In some instances, the application of an economic approach is an inevitability rather than an advancement of the social goal of the court, for example, in determining whether there is a reasonable expectation of profit in setting up a business. Valuation of property is a typical case; ${ }^{113}$ these cases do not involve the reallocation of resources.

In Moloney v. Her Majesty the Queen, ${ }^{14}$ Judge Joyal of the Federal Court Trial Division re-emphasized the common sense approach in the interpretation of the Income Tax Act. In that case, the taxpayers subscribed to a complex scheme, the results of which enable them to claim the amount each of them invested in a business venture as a business expense. Each taxpayer would invest $\$ 20,000$ but receive $\$ 17,500$ cash bond as a form of performance guarantee. The question is whether each taxpayer was entitled to claim the $\$ 20,000$ as tax deduction. The Court found that there was no business purpose with a view to making a profit and that the whole scheme was for tax benefits. Ostensibly, these investments did not enhance the efficiency of the business: no aspect of the business operation would be better off although no aspect would be worse off as a result.

After praising a paragraph from Her Majesty the Queen v. Phyllis Barbara Bronfman Trust, ${ }^{115}$ which confirms the prevalence of economic reality over juristic formalism, Judge Joyal said:

They underline an objective and common sense approach to statute interpretation and bring added respect for the commercial and economic realities of transactions which have tax connotations. It is an approach which also undermines any attempt to reduce the tenor of the statue to the absurd.

Posner, supra note 44 at 261-72; Easterbrook, supra note 99 at 14-18.

J.G. Sutherland \& S.D. Sands, eds., Statutory Construction, 4th ed. (Chicago: Callaghan, 1984) at 340 .

See Elworthy v. Her Majesty the Queen, [1982] C.T.C. 62, 82 D.T.C. 6067 (F.C.T.D.); and in M.N.R. v. Members of Northwood Country Club, [1989] 89 D.T.C. 173 (T.C.), the Tax Court of Canada had to decide which economic approach was more appropriate.

[1989] 89 D.T.C. 5099 (F.C.T.D.).

Ibid. at 5115 . 
The application of economic analysis in tax cases is not novel in Canadian federal courts although academic writers often omit this important aspect in their analyses. ${ }^{116}$ In Symes v. Her Majesty the Queen, ${ }^{117}$ Judge Cullen of the Federal Court Trial Division took economic reality into account in allowing the deduction of the nanny's salary from the income tax of the taxpayer. He took the view that it would be in line with the significant social changes in the late 1970s and into the 1980s in terms of the influx of women of child-bearing age into business and the work force. He rejected the stare decisis of the cases decided in the 1950s and the 1960s as they were based on the reasoning of a decision made in 1891. However, at the Federal Court of Appeal, the appeal by the Crown was allowed:

The Court is here being asked not only to fish in the most troubled socio-economic waters, but also to swim against the tide of a solution expressly adopted by Parliament in preference to that proposed by the respondent. 118

The Symes case indicates that judicial opinions in accepting economic reality do not reconcile. The Federal Court of Appeal clearly took the view that a strict interpretation approach should be taken as accepting the notion that economic reality is too complicated for the courts to handle. This confirms a concern that the training and background of the judges could be a factor in setting the limit of accepting economic reality. ${ }^{119}$ If economics were an exact science, the judiciary would be more ready to accept it. Lie-detector tests have been rejected as evidence because their reliability is based on psychological theories which are not exact science. ${ }^{120}$ However, breathalyser tests have been accepted as evidence because their reliability is based on medical theories which are exact science. ${ }^{121}$ In each of the following sections, we shall investigate the acceptance of economic reality in particular types of tax topics. Although this investigation is exploratory and speculative, it provides a place from which to begin.

\section{A. EMPLOYER AND EMPLOYEE RELATIONSHIP CASES}

First, we shall discuss cases involving the test of contract of service and contract for services in tax law. In determining the nature of the relationship of the parties for the purpose of the Income Tax Act, the courts look at the substance rather than the form of the contract or the intentions of the parties. The substance the courts often investigate is the economic reality.

In Marotta v. Her Majesty the Queen, ${ }^{122}$ the taxpayer, a medical doctor, argued that the income he had received from the University of Toronto was an income from

See for example, F. Woodman, "A Child Care Expenses Deduction, Tax Reform and the Charter: Some Modest Proposals" (1990) 8 Can. J. Fam. L. 371.

117 [1989] 89 D.T.C. 5243 (F.C.T.D.) [hereinafter Symes].

118 [1991] 91 D.T.C. 5397 at 5407 (F.C.A.).

119 Posner, supra note 44 at 18-19.

120 R. v. Béland, [1987] 2 S.C.R. 398 (S.C.C.).

$121 \quad R$ v. Crosthwait, [1980] 1 S.C.R. 1089 (S.C.C.).

122 [1986] 1 C.T.C. 393, 86 D.T.C. 6192 (F.C.T.D.). 
business as he was a partner with other doctors at the teaching hospital. The Federal Court Trial Division expressly used the "economic reality" test as one of the tests in determining whether a contract is a contract of service or a contract for services. The question asked here was whether the person was carrying on business for himself or for a superior, that is, who ran the risk of profit or loss? In other words, the "economic reality" test here considers who utilizes the efficiency.

\section{In City of Montreal v. Montreal Locomotive Works Ltd. et al., Lord Wright said:}

In earlier cases a single test, such as the presence or absence of control was often relied on to determine whether the case was one of master and servant, mostly in order to decide issues of tortious liability on the part of the master or superior. In the more complex conditions of modern industry, more complicated tests have often to be applied. It has been suggested that a fourfold test would in some cases be more appropriate, a complex involving (1) control; (2) ownership of the tools; (3) chance of profit; (4) risk of loss. ${ }^{123}$

One aspect of Lord Wright's tests comes down to an economic analysis, that is the question of economic risk. An independent contractor would undertake an economic risk, while an employee would not. If an employee does not supply any funds, assume any economic risks, or undertake any liability, it is obvious that a contract of service is operating. The employer would usually not suffer any additional economic loss by entering into a contract for services rather than a contract with an employee as they intended.

In contemporary society, the traditional control tests cannot be decisive for a professional person. In Boardman v. Her Majesty the Queen, ${ }^{124}$ Judge Collier expressed such a concern. The Court had to decide whether a contract between the Alberta Hospital and the psychiatrist was a contract of service or a contract for services. The contract was formed because the hospital wanted to attract well qualified psychiatrists. For efficiency, each well qualified psychiatrist could negotiate his own salary. Although the contract provided no pension rights and other fringe benefits given to doctors who were employees, the plaintiff was not required to accomplish a specified amount of work but was required to put his personal services at the disposal of the hospital. After analysing the contract and considering Alexander v. M.N.R., ${ }^{125}$ Judge Collier concluded that the contract was "as a matter of business and economic reality, an employee" contract. ${ }^{126}$ In effect, the meaning of "economic reality" in this case was the the efficient operation of the employer-employee contract.

\section{B. INCOME FROM BUSINESS}

The courts often have to consider whether the taxpayers are making any economic advantage out of their acts. If so, then the income is considered as business income. In 
determining whether an income is a business income from gaming, the court often has to draw a fine line; applying economic analysis is the only logical approach.

In Graham v. Green (Inspector of Taxes), the Tax Court took the view that the income which a person made from large scale and sustained betting on horses was not income from business as he could not "be said to organize his effort in the same way as a bookmaker organizes" his business. ${ }^{127}$ However, in Walker v. M.N.R., the Court held that the income of a farmer who regularly bet on horses for a period of about fiftythree days each year was income from business because he could not be reasonably believed to "afford to lose much money on a hobby of this kind." 128 The Court ruled that the taxpayer's intention was to embark on business and to make a profit out of it.

In Molony v. M.N.R., ${ }^{129}$ the taxpayer was dismissed from his employment with a chartered bank for having embezzled in excess of $\$ 10.2$ million to finance his gambling losses. The taxpayer appealed to the Tax Court of Canada for deduction of such losses in computing his income. The Court considered the taxpayer a pathological gambler. It was therefore self-contradictory to speak of him as being in the business of gambling since gambling had impaired his intellect and sense of perspective. Although he genuinely expected to make a profit therefrom, such expectations were unreasonable.

The above cases indicate that the courts use an objective test rather than a subjective test. In other words, the question is whether the operation of the taxpayer is, in reality, economically sound. In a betting situation, resources are allocated between the bettor and the gaming operator. If probability is taken into account, the utilities are in favour of the gaming operator. Otherwise, such operators could not be said to make a profit. The courts would take into consideration the efficiency of the specific taxpayer's operation and would not inquire into whether it is against the odds. Otherwise, no person could bet and claim the income as profit.

\section{ADVENTURE OR CONCERN IN THE NATURE OF TRADE}

In a number of cases where the courts have to decide whether a transaction is an adventure or concern in the nature of trade, the use of economic tools to analyse efficiency is inevitable. Most of these cases have been decided on whether the profit realized was a gain made in the course of business in carrying on a scheme for profit-making. Evidence from the usual trade practice and the economic analysis procedures are considered by the courts in determining the nature of the transaction. The crucial question is whether an investment or venture or concern in the nature of trade is more efficient. In considering the efficiency of the operation, the court would look at the speculative nature of the operation. A speculative operation would be a question of efficiency in the allocation of the risk. It would more likely to consider an operation to be an investment if the consideration of the taxpayer was one of confidence rather than of a speculative nature. 
In M.N.R. v. Taylor, the Court looked at the "business nature" of the transaction in deciding whether the profit from an isolated transaction was profit from an adventure or concern in the nature of trade. Thorson $J$. analysed the profit and loss and the risk assumed by the taxpayer and concluded:

He was justified in his speculative venture. The Company got the benefit of a substantial drawback of approximately $\$ 30,000$. The respondent was rehabilitated with the Company and in his own self esteem..... As for himself his venture brought him the personal satisfaction of victory as well as an increase in salary and pension rights. ${ }^{130}$

In Hughes v. Her Majesty the Queen, the Court again analysed the profit and gain of the taxpayer's business and made a comparison between the potential profits of two intervals before it concluded that "there was a change of intent to one of selling for profit." ${ }^{31}$ The entire question is when the efficiency of the operation began to maximize with a view to selling for profit. It is clear that there is always a possibility of resale should there be a reasonable offer, but this does not in itself prove the existence of a secondary intention to sell at a profit if the primary objective to invest fails. ${ }^{132}$ The court would first look at whether the primary intention is a speculative one rather than an efficient investment operation. ${ }^{133}$ An analysis of the cases ${ }^{134}$ indicates that the crucial factor the court looks at is whether the taxpayer has utilized maximum efficiency as a trader or dealer rather than as an investor.

\section{CONCLUSION}

We have discussed a few categories of cases in which the only logical approach of the courts as they deal with business and fiscal matters is to apply economic analysis. The analyses presented in Federal Court tax cases do not involve the use of complex mathematical models or economic theories, but rather represent a common sense approach. Economic methods have been used both as an analytic tool and a resource allocation tool to achieve the goal of efficiency. The continuing use of economic analysis in the Federal Court tax cases indicates that there is a judicial trend towards accepting such an approach.

There are two factors that may explain why the Canadian courts have acted as they have. The first factor is that legal scholarship in economic analysis is developing in Canada. ${ }^{135}$ On a positive side, there is a growing interest in fundamental research in

[1956] C.T.C. 189 at 216-17, 56 D.T.C. 1125 (Ex.).

[1984] C.T.C. 101 at 104, 84 D.T.C. 6110 (F.C.T.D.).

Kit-Win Holdings (1973) Ltd. v. Her Majesty the Queen, [1981] C.T.C. 43, 81 D.T.C. 5030 (F.T.C.D.).

Compare Regal Heights Ltd. v. M.N.R., [1960] 60 D.T.C. 1270 (S.C.C.) and Riznek Construction Ltd. v. Her Majesty the Queen, [1979] C.T.C. 197. In the latter case, there was no speculation and everything ran in an efficient manner. The failure to obtain a permit was due to a calculated error. Irrigation Industries Lid. v. M.N.R., [1962] C.T.C. 21S, 62 D.T.C. 1131 (S.C.C.); Atlantic Sugar Refineries Ltd. v. M.N.R., [1948] C.T.C. 326, 4 D.T.C. 507 (Ex.); Canadian Kodak Sales Ltd. v. M.N.R., [1954] C.T.C. 375, 54 D.T.C. 1194 (Ex.).

Posner, supra note 44 at $1-2$. 
Canada. ${ }^{136}$ However, the boundaries between the legal scholar's study of the tax law and the work of sociologists, economists, or political scientists writing about tax law still has to be sorted out. ${ }^{137}$

In the United States, the University of Chicago's law school is a leading proponent of law and economics. Scholarship there reached its height when faculty member, Ronald Coase, received a Nobel Prize in economics. A few justices of the United States Court of Appeal were appointed directly from the Chicago law faculty. ${ }^{138}$ There is no such school of thought in Canada. A fortiori there is no such advocate in tax law. Canadian scholarship focuses on economics and tax policies rather than on economics and judicial decisions in tax law.

The second factor is the ability of the judiciary to analyse economic techniques and to ascertain their assumptions. ${ }^{139}$ The resumes of the Canadian Supreme Court Justices provide little evidence of formal training in economic theory. ${ }^{140}$ None of them attended the University of Chicago. Most came from elite law schools in Canada and England which taught law in the traditional manner.

In view of the present state of knowledge, the degree to which the Canadian courts take economic reality into consideration seems to be logical: it avoids being dogmatic. Once the court enters into economic debates as to the pros and cons of varying economic theories, the result will be uncertain at best and chaos at worst. It should be noted that the appointment of the leading legal scholars in law and economics to the Court of Appeal in the United States has been viewed as a way to serve the economic objectives of former President Ronald Reagan.

The independence of the judiciary in Canadian tradition implies its independence from philosophical influence. If the advocates of law and economics have marketed their theories successfully in Canada, future judicial appointments are bound to be affected. Law and economics should be used as an analytical and research tool rather than as a tool for implementation.

The notable ones are Judges Robert Bork, Richard Posner, Frank Easterbrook, and Antonin Scalia. Supra note 96.

The Supreme Court of Canada (Ottawa: Minister of Supply and Services Canada, 1991). 